\title{
Pendekatan Fisik dan Ekologis Penggunaan Pohon Asam Jawa Sebagai Tanaman Tepi Jalan di Sekeliling Trotoar Lapangan Puputan Badung, Denpasar
}

\author{
NI WAYAN FEBRIANA UTAMI ${ }^{*}$, ANAK AGUNG KESWARI KRISNANDIKA ${ }^{1}$ \\ 1Program Studi Arsitektur Pertamanan, Fakultas Pertanian, Universitas Udayana \\ *E-mail: wayan_febriana@unud.ac.id
}

\section{ABSTRACT \\ Physical and Ecological Approaches to Using Tamarinds as Street Trees around the Sidewalk in Puputan Badung Parks, Denpasar}

Many streetscapes in Indonesia cities used tamarinds (Tamarindus indica L.) tress as soft scape elements and Denpasar city is also one of them. This paper is concerned with the use of tamarinds species in street trees, especially it uses around the Puputan Badung sidewalks. The objectives of this paper were to identify the positive impact of tamarinds physically and ecologically on the environment. A survey methods was employed to obtain information about the existing trees. Descriptive methods was used to analyze trees character physically and ecologically and also its suitability based on literature study. Study results showed that there were sixteen individuals of tamarinds found along the sidewalk in Puputan Badung parks. The trees distributed as many as four individuals on northern and southern part, six individuals on eastern part, and two individuals on western part of the park. Some physical characteristic of the trees have been identified, i.e. vase canopy shape to provide tree canopy cover and avoid sun glare effect, fine plant texture to expand space impression, and slow stem growth. In addition, trees ecological characteristics recognized for controlling air pollutants $\left({ }^{15} \mathrm{~N}\right.$ and $\left.\mathrm{Pb}\right)$ and also providing wildlife habitat for lac insects (Laccifer lacca) as well as providing nectar for honeybees. It is suggested that, given the contribution of tamarind trees to the environment, more and more of them should be planted as street tress, and to maintain it, the requirements of planting the trees should be taken into account.

Keywords: ecological function, Puputan Badung parks, street trees, streetscape, tamarinds

\section{Pendahuluan}

Tanaman yang dikenal dengan nama asam Jawa dalam bahasa Indonesia atau celagi dalam bahasa Bali merujuk pada tanaman dengan buah berwarna cokelat dengan rasa asam. Tanaman ini termasuk kedalam famili leguminoceae dengan nama ilmiah Tamarindus indica Linn atau dikenal dengan sebutan tamarind dalam bahasa Inggris. Dari sebagian besar sumber pustaka yang ada dijelaskan bahwa tanaman ini berasal dari Afrika Barat, dan kemudian menyebar sampai ke India dengan bukti ditemukannya arang dari tanaman asam di sebuah lokasi bernama Narhan yang terletak di antara kawasan sungai Gangga (Blench, 2008). Sebutan "tamarin" sendiri sebenarnya berasal bahasa Arab yaitu dari kata tamr hindi atau date from India yang berarti "buah kurma dari India". 
Sudah sejak lama masyarakat Indonesia mengenal jenis pohon asam Jawa. Jika diperhatikan dari asal usul namanya yaitu "asam Jawa" bermakna sebagai pohon asam yang banyak ditemukan di wilayah Jawa, khususnya Jawa Tengah. Pohon asam Jawa, terutama bagian daging buahnya, sudah sejak lama dikenal oleh nenek moyang bangsa Indonesia dan digunakan sebagai bahan baku jamu atau minuman kesehatan tradisional aseli Indonesia. Selain di Jawa Tengah, pohon asam Jawa ini juga dijumpai di wilayah lain di Pulau Jawa seperti Jawa Barat, Jawa Timur termasuk Madura. Selain itu, pohon ini juga menyebar hingga ke wilayah lain di Indonesia diantaranya di wilayah Sumatera Utara, Kalimantan Barat, Bali dan Sulawesi Selatan. Sebagian besar pohon asam Jawa yang dijumpai merupakan tanaman yang ditanam di wilayah dataran rendah utamanya sebagai tanaman tepi jalan (Soemardji, 2007).

Bali, terutama Kota Denpasar, sebagai salah satu kawasan penyebaran pohon asam Jawa, juga memiliki jenis tanaman ini sebagai tanaman tepi jalan. Keberadaan tanaman asam Jawa secara tidak langsung memberi manfaat sebagai tanaman eksotik tepi jalan sekaligus memiliki manfaat secara ekologis sebagai penyedia udara bersih bagi wilayah kota (SLH Kota Denpasar, 2008). Di kota Denpasar sendiri, tanaman asam Jawa banyak ditemukan di di beberapas ruas jalan utama di pusat kota Denpasar seperti jalan Gajah Mada, jalan Veteran, jalan Surapati, maupun bagian lainnya. Salah satu area yang masih banyak dijumpai tanaman asam Jawa adalah area di sekitar lapangan Puputan Badung tepatnnya mengelilingi lapangan Puputan Badung yang merupakan salah satu elemen lunak pembentuk ruang terbuka hijau perkotaan (RTHK). Sehinga dengan adanya latar belakang tersebut maka penelitian ini dilakukan dalam rangka mengetahui sebaran tanaman asam Jawa yang ada di sekeliling Lapangan Puputan Badung sekaligus mengetahui fungsi tanaman tersebut dalam memberikan dampak positif bagi lingkungan.

\section{Metode}

\subsection{Waktu dan Lokasi Penelitian}

Studi ini dilakukan di kawasan Lapangan Puputan Badung, Kota Denpasar, Provinsi Bali pada bulan Mei sampai Juni 2016. Letak geografis wilayah penelitian berada diantara $8^{\circ} 39^{\prime 2} 22^{\prime \prime}-8^{\circ} 39^{\prime} 29^{\prime \prime}$ LS dan 115¹3'00"-115¹3'06" BT (Gambar 1).

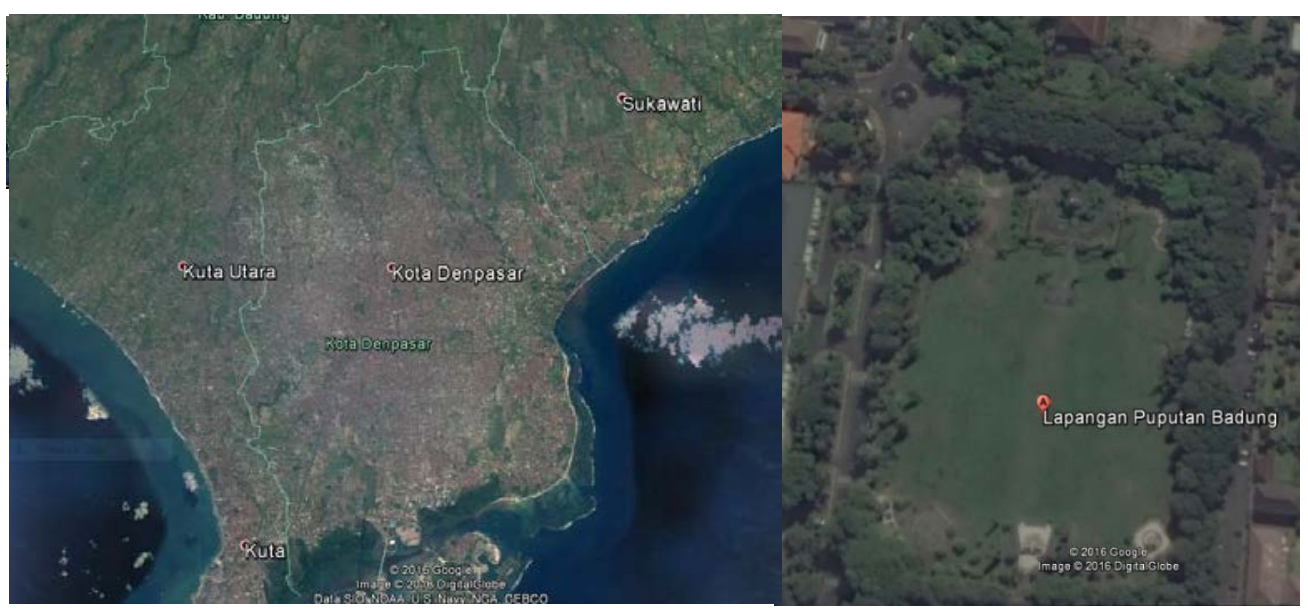

Gambar 1. Peta Lokasi Studi 
Penelitian dilakukan dengan melalui beberapa tahap yaitu tahap inventarisasi dengan melalukan survei tanaman. Berikutmya dilanjutkan pada tahap analisis dengan melakukan analisis spasial dan analisis deskriptif. Tahap terakhir yaitu tahap sintesis dengan melakukan analisis deskriptif kesesuaian pohon asam Jawa secara fisik dan ekologis berdasarkan studi literatur sehingga menghasilkan rekomendasi tanaman asam Jawa sebagai tanaman tepi jalan. (Gambar 2).

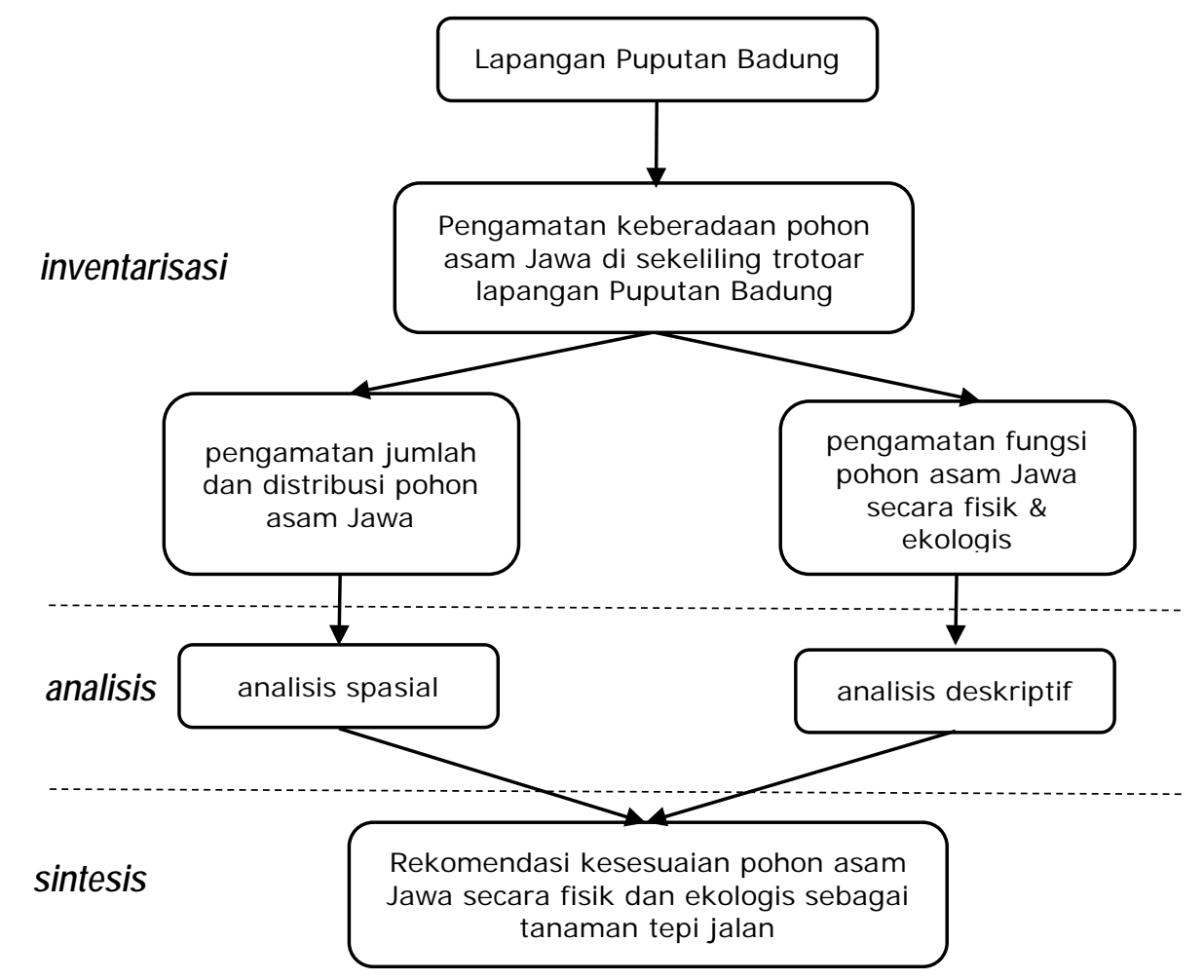

Gambar 2. Bagan Alur Penelitian

\subsection{Metode Penelitian}

Penelitian ini menggunakan beberapa metode diantaranya adalah untuk pengumpulan data menggunakan metode survey tanaman sedangkan untuk analisis data menggunakan metode analisis spasial dan analisis deskriptif.

\subsection{Metode Pengumpulan Data}

Pada tahap pengumpulan data dilakukan kegiatan pengamatan terhadap keberadaan pohon asam Jawa yang ada di sekeliling trotoar lapangan Puputan Badung. Kegiatan dimulai dengan menginventarisasi jumlah tanaman asam Jawa serta sebaran tanaman dengan menggunakan GPS. Selain itu dilakukan pengamatan dan pencatatan ciri fisik tanaman disertai dengan pengambilan foto tanaman yang ada di sekeliling trotoar. Untuk mengetahui kesesuaian fisik tanaman sebagai tanaman tepi jalan maka dilakukan penelusuran literatur tentang ruang tumbuh tanaman dan kegiatan konstruksi trotoar (lebar trotoar, lebar kanopi, kondisi akar, kondisi tanah), seleksi jenis pohon (desain bentuk, tekstur, warna, akar dan percabangan), kondisi tanah dan keberadaan infrastruktur terkait pemeliharaan (City of New York Park \& Recreation, 2014; Permen PU No. 5 Tahun 2012; 
Federation of Canada Municipalities and National Research Council, 2004) yang diselaraskan dengan data hasil pengamatan. Sedangkan untuk mengetahui kesesuaian ekologis pohon asam Jawa sebagai tanaman tepi jalan maka dilakukan studi literatur mengenai jenis serapan terhadap polutan dan keberadaan satwa (Permen PU No. 5 Tahun 2012).

\subsection{Metode Analisis Data}

\subsubsection{Metode Analisis Spasial}

Distribusi pohon asam Jawa dipetakan dengan melakukan perekaman koordinat pohon dengan menggunakan GPS. Setelah perekaman koordinat pohon didapat kemudian dipetakan sebarannya dengan menggunakan peta dasar yang berasal dari Google map yang diolah dengan menggunakan perangkat lunak ArcGIS 10.4. Hasil akhir berupa peta sebaran pohon asam Jawa yang ada di sekeliling lapangan Puputan Badung.

\subsubsection{Metode Analisis Deskriptif}

Untuk mengetahui kesesuaian pohon asam Jawa sebagai tanaman tepi jalan digunakan metode analisis deskriptif kualitatif dengan menghubungkan karakter fisik pohon asam Jawa dengan kajian tentang standar pohon sebagai tanaman tepi jalan dan trotoar maupun kajian tentang manfaat pohon Asam Jawa bagi ekologi perkotaan.

\section{Hasil dan Pembahasan}

\subsection{Kondisi Umum Lapangan Puputan Badung}

Lapangan Puputan Badung "I Gusti Ngurah Made Agung merupakan sebuah ruang terbuka hijau kota yang terletak tepat di tengah kota Denpasar, yaitu terletak pada titik kilometer nol perhitungan jarak di provinsi Bali sekaligus berada pada zona Pempatan Agung atau pola ruang perempatan yang disakralkan bagi masyarakat Bali maupun Jawa (Hermanislamet, 1999). Luas lapangan ini adalah sekitar $\pm 35.691 \mathrm{~m}^{2}$ yang dikelilingi oleh jalan-jalan utama di Kota Denpasar yaitu di sebelah utara adalah jalan Surapati dan sebelah timur adalah jalan Mayor Wisnu, namun jalan ini kemudian ditutup aksesnya di bagian utara namun di bagian selatan memungkinkan untuk diakses untuk difungsikan menjadi area parkir kendaraan menuju museum Bali. Selanjutnya untuk batas tapak di bagian selatan adalah jalan Beliton dan batas sebelah barat adalah jalan Udayana (Gambar 3).

Menurut sejarah, keberadaan lapangan Puputan Badung merupakan wujud penghormatan terhadap pahlawan I Gusti Ngurah Made Agung yang berjuang pada peristiwa perang puputan (perang habis-habisan) melawan penjajah Belanda dalam mempertahankan kedaulatan kerajaan Badung. Penetapan nama ini berdasarkan Surat Keputusan Walikota Denpasar Nomor 188.45/585/HK/2009 (situs pemerintahan Kota Denpasar, 2016). Kemudian bentuk penghormatan terhadap perjuangan rakyat Bali dalam perang yang dipimpin oleh I Gusti Ngurah Made Agung ini kemudian diwujudkan dengan dibangunnya monumen puputan Badung. Pembangunan monumen terletak di bagian utara tapak. Secara umum aktivitas yang mendominasi tapak ini adalah kegiatan rekreasi, olahraga, dan pameran baik yang dilakukan secara insidentil maupun terjadwal. 
Berdasarkan pengamatan, pemanfaatan tapak tergolong sangat tinggi yaitu digunakan mulai pagi hari hingga malam hari dan variasi aktivitas yang beragam.

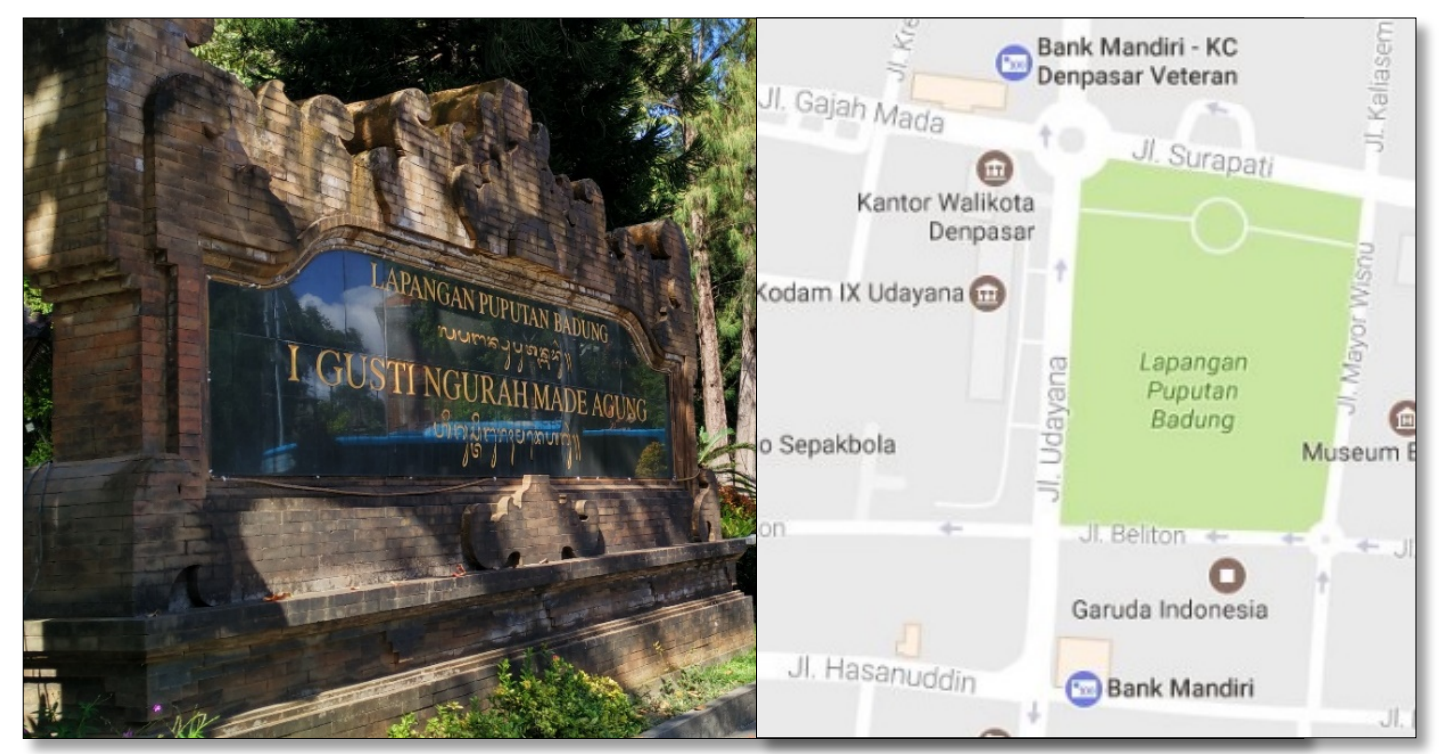

Gambar 3. Lapangan Puputan Badung "I Gusti Ngurah Made Agung"

\subsection{Tanaman Asam Jawa dan Sebarannya}

Asam Jawa (Tamarindus indica L.) termasuk tumbuhan tropis tergolong kedalam famili leguminoceae atau tanaman kacang-kacangan. Asal usul dari tanaman ini diperkirakan berasal dari Afrika bagian barat kemudian terdistribusi ke wilayah India dan Asia Tenggara termasuk ke Indonesia. Pohon asam Jawa tumbuh dengan baik pada ketinggian mencapai $1.500 \mathrm{~m}$ dpl dengan curah hujan rata-rata tahunan 500-1.500 mm dan jenis tanah alluvial dalam yang memiliki aerasi baik. Habitus tanaman asam Jawa berupa pohon berdaun hijau (evergreen) dengan ketinggian mencapai 30 meter dan diameter batang di bagian pangkal mencapai $2 \mathrm{~m}$, toleran pada suhu sampai $47 \circ \mathrm{C}$ namun sensitif terhadap pembekuan. Tanaman asam Jawa memiliki beragam nama lain yaitu asam Jawa (bahasa Indonesia), celagi (bahasa Bali), asang Jawi (Sulawesi), sampalok/kalamangi (Tagalog), magyee (Burma), ma-kham (Thai), khaam (Laos), khoua me (Kamboja), trai me (Vietnam), tamarind atau Indian date (Eng), tamarinde (Afrika), atau tamrulhindi (India).

Tanaman asam Jawa merupakan jenis tanaman tepi jalan yang lazim dijumpai di beberapa kota di Indonesia seperti di Jawa Barat, Jawa Tengah, Jawa Timur termasuk Madura, Sumatera Utara, Kalimantan Barat, Sulawesi Selatan dan Bali (Soemardji, 2007). Di Kota Denpasar sendiri sebaran tanaman asam Jawa yang masih bisa dijumpai di pusat kota diantaranya di ruas jalan seperti jalan Veteran, jalan Kaliasem, jalan Surapati, jalan Udayana, jalan Beliton, jalan Letda Regug dan jalan Gajah Mada dengan jumlah terbatas dan tidak merata dijumpai pada sepanjang ruas jalan. Pemilihan lokasi pengamatan yang berada di sekeliling lapangan Puputan menjadi pertimbangan karena keberadaan tanaman yang lebih konsisten dibandingkan ruas jalan lainnya dan juga peran utama lapangan 
Puputan Badung yang sangat penting sebagai salah satu penyedia ruang publik bagi masyarakat yang tinggal di Kota Denpasar.

Berdasarkan hasil pengamatan terdapat keberadaan tanaman asam Jawa, ditemukan sebanyak enam belas individu tanaman asam Jawa dengan sebaran sebagai berikut yaitu sebanyak masing-masing empat tanaman di sebelah utara dan selatan lapangan, sebanyak enam tanaman di sebelah timur lapangan, dan sebanyak dua tanaman di bagian barat lapangan (Gambar 4). Diantara keenam belas tanaman tersebut, diameter setinggi dada (dbh) tertinggi dicapai oleh individu nomer 1 (terletak di sebelah timur lapangan) dengan nilai dbh yaitu $159 \mathrm{~cm}$ dan terendah dicapai oleh individu nomer 11 (terletak di sebelah selatan lapangan) dengan nilai dbh yaitu $45 \mathrm{~cm}$ (Tabel 1).

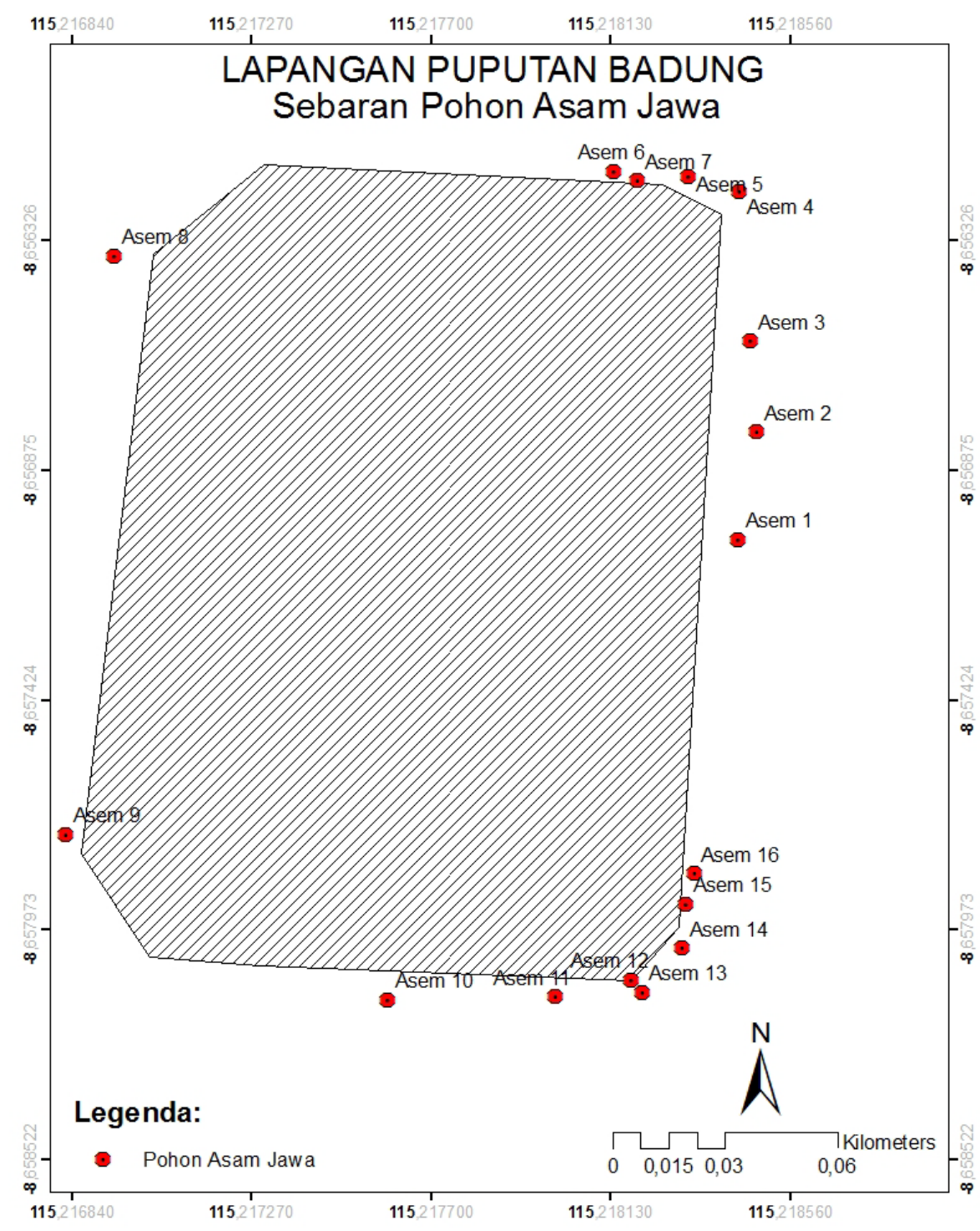

Gambar 4. Peta Sebaran Pohon Asam Jawa 
Adanya perbedaan pada diameter tanaman asam Jawa memberikan pengaruh yang berbeda terhadap kondisi jalan maupun trotoar yang ada disekitar area tumbuh tanaman. Hal ini seperti diungkapkan oleh Francis et.al. (1996) yang menyatakan bahwa pengamatan terhadap tanaman mahoni sebagai tanaman tepi jalan dengan kondisi diameter yang kecil memberikan peluang terjadinya kerusakan pada trotoar atau badan jalan senilai nol atau bahkan tidak ada kerusakan sama sekali. Hal ini dapat dipahami bahwa ukuran diameter memiliki korelasi terhadap terjadinya peluang merusak struktur jalan. Namun lebih lanjut dijelaskan juga bahwa setelah tanaman mencapai diameter maksimal pertumbuhan maka peluang untuk merusak menjadi melambat. Sedangkan untuk tanaman asam Jawa menurut Francis et.al. (1996) merupakan jenis tanaman yang peluangnya sedikit sekali dalam merusak struktur jalan.

Tabel 1. Sebaran dan Diameter Setinggi Dada (dbh) Tanaman Asam Jawa Serta Material Konstruksi Jalan di Sekeliling Lapangan Puputan Badung

\begin{tabular}{cccc}
\hline $\begin{array}{c}\text { Kode } \\
\text { Pohon }\end{array}$ & Diameter setinggi dada/dbh (cm) & $\begin{array}{c}\text { Lokasi dijumpai pada } \\
\text { tapak pengamatan }\end{array}$ & $\begin{array}{c}\text { Material konstruksi } \\
\text { jalan }\end{array}$ \\
\hline 1 & 159 & Timur & paving blok \\
2 & 111 & Timur & paving blok \\
3 & 83 & Timur & paving blok \\
4 & 80 & Utara & aspal \\
5 & 88 & Utara & aspal \\
6 & 57 & Utara & aspal \\
7 & 64 & Utara & aspal \\
8 & 76 & Barat & aspal \\
9 & 105 & Barat & aspal \\
10 & 67 & Selatan & aspal \\
11 & 45 & Selatan & aspal \\
12 & 99 & Selatan & aspal \\
13 & 70 & Selatan & aspal \\
14 & 72 & Timur & paving blok \\
15 & 81 & Timur & paving blok \\
16 & 61 & Timur & paving blok \\
\hline Sumber: Observasi, 2016 & & & \\
& & & \\
\hline & & &
\end{tabular}

\subsection{Fungsi Fisik dalam Ekologis Tanaman Asam Jawa sebagai Tanaman Tepi Jalan}

Berdasarkan definisi yang dikeluarkan oleh Kementerian Pekerjaan Umum nomor 5/PRT/M/2012 tentang "Pedoman Penanaman Pohon pada Sistem Jaringan Jalan" dijelaskan bahwa jalan merupakan prasarana transportasi darat yang meliputi segala 
bagian jalan, termasuk bangunan pelengkap dan perlengkapannya yang diperuntukkan bagi lalu lintas yang berada pada permukaan tanah, di atas permukaan darat, di bawah permukaan tanah dan atau air serta di atas permukaan air, kecuali jalan kereta api, jalan lori, dan jalan kabel. Dalam Permen tersebut diatur tentang bagaimana perencanaan, pelaksanaan, dan pemeliharaan tanaman pada ruang milik jalan (rumija), termasuk trotoar sebagai jalur pejalan kaki yang merupakan bagian dari ruang manfaat jalan (rumaja) yang menjadi bagian dari rumija. Trotoar adalah atribut jalan yang juga memerlukan penataan, termasuk penanaman pohon agar tujuan dari kenyamanan pengguna pejalan kaki untuk tujuan kenyamanan, keindahan dan keamanan dapat dicapai.

Menurut dewan riset dan federasi kota Kanada/FCMNRC (2004), terdapat persyaratan penanaman pohon pada trotoar, antara lain 1) ketersediaan ruang yang cukup bagi perkembangan pohon maupun konstruksi, 2) pemilihan spesies pohon seperti syarat desain dalam hal bentuk, tekstur, warna, maupun syarat ekologis, dan 3) jenis tanah, meliputi tingkat permeabilitas dan ketersediaan tanah struktur. Dilihat dari ketersediaan ruang tumbuh dari tanaman asam Jawa, dari hasil pengamatan dapat diketahui bahwa secara umum tanaman asam Jawa berada tepat setelah trotoar dan tumbuh di atas material jalan. Terdapat dua jenis material konstruksi jalan yang digunakan di sekililing lapangan Puputan Badung dimana tanaman asam Jawa tumbuh yaitu pada sisi sebelah utara, barat, dan selatan menggunakan material aspal, sedangkan di bagian timur yang saat ini dimanfaatkan sebagai area parkir kendaraan bagi pengunjung museum maupun lapangan menggunakan material paving (Tabel 1). Kedua jenis material konstruksi tersebut tentu saja memiliki karakteristik yang berbeda yang mempengaruhi usia penggunaan dari struktur jalan termasuk trotoar (Gambar 5). Perbandingan tersebut dapat dilihat dari usia harapan penggunaan. Aspal memiliki harapan usia penggunaan sebesar 40 tahun sedangkan paving sebesar 80 tahun jika diaplikasikan sebagai material trotoar (FCMNRC, 2004).

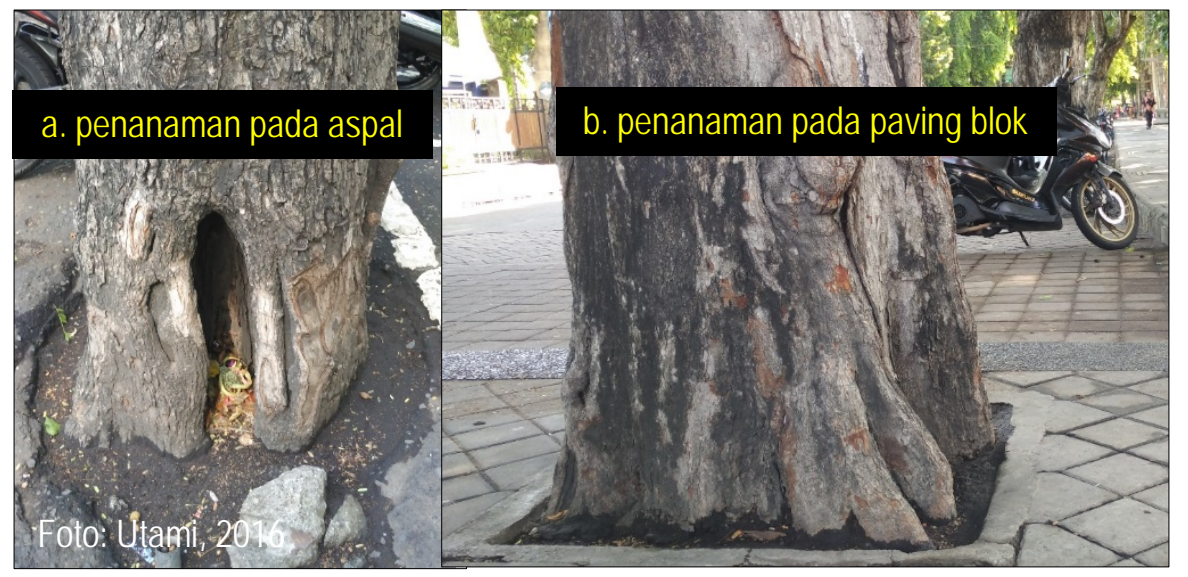

Gambar 5. Perbedaan Pertumbuhan Asam Jawa Pada Jenis Material Konstruksi Aspal dan Paving Blok 
Dari penjelasan di atas maka dapat diasumsikan bahwa tingkat kerusakan jalan yang diakibatkan oleh penanaman tanaman tepi jalan jika dilihat dari material konstruksinya menjadi lebih tinggi pada jenis material konstruksi aspal. Selain itu juga tanaman asam Jawa memiliki karakter pertumbuhan akar yang lambat sehingga perakaran tanaman asam Jawa tidak menggangu kontruksi jalan. Namun hal ini tentu saja bukan merupakan satusatunya faktor yang mempengaruhi tingkat kerusakan struktur jalan. Lebih lanjut dijelaskan bahwa buruknya desain dan konstruksi trotoar serta pemeliharaan yang tidak sesuai standar juga dapat menyebabkan terjadinya kerusakan pada trotoar. Kegagalan dalam mencapai tiga faktor seperti yang dimaksud FCMNRC (2004) maka konflik antara pohon dan trotoar tidak dapat dihindari (Randrup et. al., 2001).

Berdasarkan karakter tanaman asam Jawa dapat diketahui bahwa tanaman asam Jawa memiliki arsitektur tajuk berbentuk vas yaitu memiliki kanopi menyebar di bagian atas, bentuk kanopi seperti ini mampu memberikan tutupan selebar kanopi pohon sehingga mampu menghalau silau cahaya matahari. Jika dilihat dari sebaran tanaman asam Jawa yang lebih banyak ada di bagian timur lapangan bukan berarti bagian lainnya tidak memiliki tutupan kanopi yang cukup. Hal ini dikarenakan selain tanaman asam Jawa terdapat jenis tanaman tepi jalan lainnya yang ditanam yaitu pohon angsana. Disisi lain tekstur daun yang halus dapat menghasilkan kesan ruang lebih luas. Hal ini menjadi penting dalam desain dimana reka ruang diperlukan untuk mencapai kesan ruang tertentu sebagaimana konsep desain yang diharapkan. Selain bentuk kanopi tajuk dan tektur daun, unsur desain warna juga menjadi pertimbangan. Tanaman asam Jawa yang berwarna hijau menimbulkan kesan sejuk selain buahnya yang berwarna coklat dan bunganya berwarna kuning kecoklatan memberikan aksen pada tanaman tersebut.

Beralih pada jasa lingkungan yang diberikan dari tanaman asam Jawa. Dari beberapa kajian literatur yang ada dua jasa lingkungan yang diberikan oleh tanaman asam Jawa. Menurut Patra et.al. (2004) bahwa tanaman asam Jawa mampu menyerap unsur ${ }^{15} \mathrm{~N}$ sebesar $80,47 \mu / g r$ dalam kondisi terang atau menduduki peringkat ketiga setelah tanaman jati puth dan jati super. Gas $\mathrm{NO}_{2}$ merupakan polutan yang berasal dari kendaraan yang membahayakan lingkungan maupun manusia. Oleh sebab itu penanaman asam Jawa sebagai tanaman tepi jalan memberian dampak yang baik bagi lingkungan. Selain gas nitrogen oksida, jenis polutan lain berasal dari logam berat timbal (Pb) dimana dari hasil penelitian yang dilakukan oleh (Samsoedin et.al., 2015) tanaman asam Jawa yang ditanam di daerah Bekasi memiliki kemampuan menjerap polutan sebesar 0,0856 $\mathrm{g} / \mathrm{cm}^{2}$ atau yang paling tinggi dibandingkan jenis tanaman tepi jalan lainnya sehingga berkontribusi dengan baik terhadap peningkatan kualitas udara. Di sisi lain, keberadaan tanaman asam Jawa juga menunjang kelangsungan hidup satwa liar seperti lebah madu. Di daerah Indian selatan, bunga dari tanaman asam Jawa menjadi sumber utama nectar dari lebah madu (Morton, 1987). Biasanya madu yang dihasilkan dari nectar bunga asam Jawa berwarna kuning dan memiliki rasa sedikit asam. Pertimbangan lain yang juga menjadi perhatian dalam pemanfaatan tanaman asam Jawa sebagai tanaman tepi jalan adalah pemangkasan pada tanaman dewasa. Dengan perencanaan kegiatan pemeliharaan tanaman terutama setelah tanaman mencapai usia dewasa maka hal-hal 
yang tidak diinginkan dari bentuk tanaman dewasa ini dapat dihindari misalnya ketinggian tanaman yang diatur sedemikian rupa sehingga tida membahayakan utilitas jalan seperti lampu penerangan maupun kabel-kabel listrik dan telepon.

\section{Simpulan}

Simpulan dari penelitian ini adalah bahwa menyadari adanya fungsi fisik dan ekologis tanaman asam Jawa dan juga potensi kerusakan yang mungkin muncul membutuhkan baik untuk fungsi sebagai tanaman tepi jalan maupun trotoar dapat meningkatkan peluang penggunaan tanaman asam Jawa sebagai tanaman tepi jalan.

\section{Daftar Pustaka}

Badan Lingkungan Hidup Kota Denpasar. 2008. Status Lingkungan Hidup (SLH) Kota Denpasar

Blench, Roger. 2008. A history of fruits on the Southeast Asian mainland. Ed: Toshiki Osada and Akinori Uesugi. In: Occasional Paper 4: Linguistics, Archeology and the Human Past. Indus Project Research Institute for Humanity and Nature, Kyoto, Japan

City of New York Park and Recreation. 2014. Tree Planting Standards.

City of New York Park and Recreation. 2014. Tree Planting Standards. https://www.nycgovparks.org/pagefiles/53/Tree-Planting-Standards.pdf

Federation of Canada Municipalities and National Research Council, 2004. Sidewalk Design, Construction and Maintenance. Issue No. 1.0

Francis, J.K., B. R. Parresol, and J.M. de Patino. 1996. Probability of Damage to Sidewalks and Curbs by Street Trees in the Tropics. Journal of Arboriculture 22(4): July 1996. Pp 193-197

Kementerian Pekerjaan Umum. 2012. Peraturan Menteri Pekerjaan Umum No. 5/PRT/M/2012/ Tentang Pedoman Penanaman Pohon pada Sistem Jaringan Jalan

Morton, J. 1987. Tamarind. P. 115-121. In: Fruits of Warm Climates. J. F., Morton. Miami, Florida

Patra, A.D., N. Nasrullah, E.L. Sisworo. 2004. Kemampuan Berbagai Jenis Tanaman Menyerap Gas Pencemar Udara $\left(\mathrm{NO}_{2}\right)$. Risalah Seminar Ilmiah Penelitian dan Pengembangan Aplikasi Isotop dan Radiasi

Pemerintah Kota Denpasar. 2012. Monumen Puputan Badung I Gusti Ngurah Made Agung. http://denpasarkota.go.id/index.php/detail-datang-kunjungi/21/MonumenPuputan-Badung-I-Gusti-Ngurah-Made-Agung

Randrup, T.B., E.G. McPherson, L.R. Costello. A Riview of Tree Root Conflics with Sidewalks, Curbs, and Roads. Urban Ecosystem, 5: 209-225. Kluwer Academic Publisher

Samsoedin, I., I.W. Susidharmawan, Pratiwi, D. Wahyono. 2015. Peran Pohon dalam Menjaga Kualitas Udara di Perkotaan. Forda Press. 105 hal

Soemardji, Andreanus A. 2007. Tamarindus indica L. or "Asam Jawa": The Sour but Sweet and Useful. NII - Electronic Library Service - University of Toyama, Japan. 